\title{
High expression and nuclear localization of $\beta$-catenin in diffuse large B-cell lymphoma
}

\author{
XUELING GE ${ }^{1}$, XIAO LV ${ }^{1}$, LILI FENG ${ }^{1}$, XIAOQIAN LIU ${ }^{2}$ and XIN WANG ${ }^{1}$ \\ ${ }^{1}$ Department of Hematology, Provincial Hospital Affiliated to Shandong University, Jinan, Shandong 250021; \\ ${ }^{2}$ Department of Hematology, Yantai Yuhuangding Hospital, Affiliated Hospital of the Medical College, \\ Qingdao University, Yantai, Shandong 264000, P.R. China
}

Received October 21, 2011; Accepted February 28, 2012

DOI: $10.3892 / \mathrm{mmr} .2012 .835$

\begin{abstract}
The Wnt/ $\beta$-catenin signaling pathway plays diverse roles in embryonic development and maintenance of organs and tissues in adults as well as in the pathogenesis of a range of diseases, including many types of carcinomas. $\beta$-catenin, the principal downstream effector of the $\mathrm{Wnt} / \beta$-catenin pathway, migrates to the nucleus and mediates the activation of the Wnt/ $\beta$-catenin pathway. The aim of the present study was to investigate the expression and localization of $\beta$-catenin in diffuse large B-cell lymphoma (DLBCL) tissues and to illuminate the role of $\beta$-catenin in the pathogenesis of DLBCL. The mRNA expression levels of $\beta$-catenin were determined by quantitative polymerase chain reaction (PCR), while $\beta$-catenin protein levels were detected by western blot analysis and immunohistochemical staining. DLBCL showed a higher expression of $\beta$-catenin in contrast to reactive hyperplasia of lymph node tissues at both the mRNA and protein levels $(\mathrm{P}<0.001)$. Immunohistochemical analysis indicated nuclear localization of $\beta$-catenin in 14 (46.67\%) DLBCL cases, whereas no inflammatory lymph node tissue showed nuclear accentuation of $\beta$-catenin. The overexpression and nuclear accentuation of $\beta$-catenin were strongly correlated to the clinical staging of patients with DLBCL $(\mathrm{P}<0.05)$. These results suggest that the $\mathrm{Wnt} / \beta$-catenin pathway is partly activated in DLBCL and may contribute to its pathogenesis.
\end{abstract}

\section{Introduction}

Diffuse large B-cell lymphoma (DLBCL) is an aggressive malignancy of mature $B$ lymphocytes and is the most common type of lymphoma in adults $(1,2)$. DLBCL accounts for $25-30 \%$ of adult non-Hodgkin lymphoma in the West and its prevalence is even greater in developing countries $(3,4)$.

Correspondence to: Professor Xin Wang, Department of Hematology, Provincial Hospital Affiliated to Shandong University, No. 324 Jingwu Road, Jinan, Shandong 250021, P.R. China

E-mail: xinwang55@yahoo.com.cn

Key words: diffuse large B-cell lymphoma, $\beta$-catenin, nuclear localization, signaling pathway
The pathogenesis of DLBCL remains unknown; however, a number of constitutively activated growth signaling pathways have frequently been observed in DLBCL, including phosphatidylinositol 3-kinase/AKT (PI3K/Akt), nuclear factor $\kappa \mathrm{B}$ $(\mathrm{NF}-\kappa \mathrm{B})$ and $\mathrm{Wnt} / \beta$-catenin signaling pathways (5-9).

The Wnt $/ \beta$-catenin signaling pathway plays a notable role in embryonic development and in the maintenance of organs and tissues in adults $(10,11)$. Numerous studies have indicated that the Wnt/ $\beta$-catenin pathway is also involved in the pathogenesis of a range of diseases, including several types of carcinomas (12). In the absence of a Wnt ligand binding to its receptor complex, the cytoplasmic $\beta$-catenin is degraded by the 'destruction complex'. In this complex, Axin acts as a scaffold protein, to which adenomatous polyposis coli (APC), glycogen synthase kinase $3 \beta(\mathrm{GSK}-3 \beta)$ and casein kinase $1 \alpha$ $(\mathrm{CK} 1 \alpha)$ bind to facilitate the sequential phosphorylation of $\beta$-catenin in 45 serine by kinase $\mathrm{CK} 1 \alpha$ and 41 'threonine, 37 ',33'serine by GSK-3 $\beta(13,14)$. Accordingly, phosphorylated $\beta$-catenin is recognized by $\beta$-transducin-repeat-containing protein $(\beta-\mathrm{TrCP})$ and constantly degraded by the ubiquitinproteasome pathway. Wnt signaling is activated via ligation of Wnts, which is a group of secreted cysteine-rich glycoproteins, to their respective dimeric cell surface receptors composed of the seven transmembrane frizzled $(\mathrm{Fz})$ proteins and the low-density lipoprotein receptor-related protein 5/6 (LRP5/6). Upon ligation to their receptors, the cytoplasmic protein disheveled (Dvl) is recruited, phosphorylated and activated. Activation of Dvl induces the dissociation of GSK-3 $\beta$ from Axin and leads to the inhibition of GSK-3 $\beta$. The phosphorylation and degradation of $\beta$-catenin is then inhibited as a result of the inactivation of the destruction complex. Subsequently, stabilized $\beta$-catenin translocates into the nucleus. Nuclear $\beta$-catenin is the ultimate effector, binding to Tcf/Lef ( $\mathrm{T}$ cell factor and lymphoid-enhancing factor) transcription factors that lead to changes in the expression of different target genes that regulate cell proliferation, differentiation and survival, cell polarity and even angiogenesis (15).

The Wnt/ $\beta$-catenin pathway plays an important role in the progression of leukemia, myeloma (16-19) and several subtypes of lymphoma, such as Epstein-Barr virus (EBV)positive Burkitt's lymphoma (BL) (20-22), mantle cell lymphoma (MCL) (23-25), cutaneous lymphoma (26), extranodal marginal zone lymphoma (27), ALK-positive anaplastic 
large cell lymphoma (28), small B-cell lymphoma (29) and DLBCL (9,30). Scientists demonstrated that ethacrynic acid (EA) and the antifungal agent ciclopirox olamine (cic) inhibited the Wnt/ $\beta$-catenin signaling in OPM-2 myeloma and three lymphoma cell lines (OCI-LY8-LAM-53, SU-DHL-4 and Raji) in vitro, leading to apoptosis and a significant decrease in the viability of lymphoma and its cell lines (30). The Hedgehog (Hh) inhibitor, cyclopamine, and the Wnt inhibitor, quercetin, suppressed the growth of a number of types of leukemia and lymphoma cells (31). The gene expression profiles (GEP) of one rituximab unresponsive and two responsive DLBCL cell lines showed that in the responsive cells rituximab affected the expression of genes in classical signaling cascades involved in cell growth and differentiation, such as previously identified MAPK and the completely novel Wnt and TGF- $\beta$ pathways (9). These findings demonstrate that aberrant activation of the Wnt/ $\beta$-catenin pathway may be important for DLBCL development and progression.

$\beta$-catenin is the chief downstream effector of the Wnt/ $\beta$-catenin pathway that migrates to the nucleus and mediates the activation of the $\mathrm{Wnt} / \beta$-catenin pathway. The present study aimed to investigate the expression and localization of $\beta$-catenin in DLBCL tissues and to illuminate the role of $\beta$-catenin in the pathogenesis of DLBCL.

\section{Materials and methods}

Patients and samples. Paraffin-embedded archived samples, including 30 cases of DLBCL diagnosed according to the WHO criteria between January 2008 and December 2010 (32), and 20 reactive hyperplasia of lymph node tissues, were obtained from the Shandong Provincial Hospital. Twenty-one biopsies of DLBCL tissues and 25 tissues from patients of reactive hyperplasia of the lymph nodes were frozen and stored in liquid nitrogen until further use. The protocol was approved by the Shandong Provincial Hospital Ethics Committee and consent forms were signed by all subjects in this study.

Reverse transcription-polymerase chain reaction $(P C R)$ and real-time quantitative $P C R$. Total RNA was extracted from tissues using TRIzol (Invitrogen). Reverse transcription reaction was then conducted by means of Takara reverse transcription reagents (Takara, Dalian, China). The reaction was incubated at $37^{\circ} \mathrm{C}$ for $15 \mathrm{~min}$ and $85^{\circ} \mathrm{C}$ for $5 \mathrm{sec}$. Amplification reactions were performed using SYBR Premix Ex Taq (Perfect Real Time; Takara) using the ABI 7500 Real-Time quantitative PCR System with cycling as follows: an initial cycle for $2 \mathrm{~min}$ at $95^{\circ} \mathrm{C}$, followed by 40 bi-phasic cycles of $15 \mathrm{sec}$ at $95^{\circ} \mathrm{C}$ and $1 \mathrm{~min}$ at $60^{\circ} \mathrm{C}$. PCR products were confirmed as a single product at the desired size on agarose gels and visualized by ethidium bromide staining. Specific primers for RT-PCR were obtained from Biosune (Shanghai, China), and the primer sequences were: human $\beta$-catenin, forward 5'-TGGCAGCAACAGTCTTACCT-3', reverse 5'-CATAGCAGCTCGTACCCTCT-3', and human- $\beta$-actin, forward 5'-TGACGTGGACATCCGCAAAG-3', reverse 5'-CTGGAAGGTGGACAGCGAGG-3'. Expression data were normalized to the geometric mean of the housekeeping gene $\beta$-actin to control the variability in expression levels and analyzed using the $2^{-\triangle \Delta C T}$ method.
Western blot analysis. Total protein was extracted from DLBCL tumors and reactive hyperplasia of lymph node tissues using RIPA and 1\% PMSF (Shenergy Biocolor, Shanghai, China), according to the manufacturer's instructions. The protein concentration of the samples was determined by the BCA assay (Shenergy Biocolor). Cell lysates were then electrophoresed on $10 \%$ SDS-polyacrylamide gels and transferred onto nitrocellulose membranes. After the membranes were blocked with $5 \%$ skim milk in Tris-saline buffer with $0.1 \%$ Tween-20, they were subsequently probed with primary antibodies at $4^{\circ} \mathrm{C}$ overnight. After washing with TBST, secondary antibody conjugated with the horseradish peroxidase (Zhongshan Goldenbridge Biotechnology Company, Beijing, China) was added to the membranes. Subsequently, proteins were detected using the chemiluminescence detection kit (Millipore, Billerica, MA, USA). Antibodies used in this study included rabbit anti- $\beta$-catenin polyclonal antibody (1:5,000; Abcam, Cambridge, MA, USA) and mouse anti$\beta$-actin monoclonal antibody $(1: 10,000$; Abcam). Western blotting results were analyzed using the Las-4000 Image software and Multi Gauge Ver. 3.0 software (FujiFilm Life Science, Tokyo, Japan).

Immunohistochemical analysis. In brief, formalin-fixed, paraffin-embedded tissue sections of $4-\mu \mathrm{m}$ were deparaffinized and hydrated. High-pressure antigen retrieval was performed using citrate buffer $(\mathrm{pH}$ 6.0). Endogenous peroxidase was quenched with $3 \%$ hydrogen peroxide in methanol for $15 \mathrm{~min}$, followed by incubation with normal serum to block non-specific staining. Rabbit anti- $\beta$-catenin $(1: 1,500)$ was then incubated with the sections overnight in a humidified chamber at $4^{\circ} \mathrm{C}$; the secondary antibody was from the SP reagent kit (Zhongshan Goldenbridge Biotechnology Company). After washing, the tissue sections were treated with biotinylated antirabbit secondary antibody, followed by further incubation with streptavidin-horseradish peroxidase complex. After staining with diaminobenzidine kit (DAB; Zhongshan Goldenbridge Biotechnology Company), the sections were counterstained with hematoxylin and mounted. Immunohistochemical staining of samples and negative controls occurred simultaneously, and the primary antibody was replaced with PBS for the negative controls.

Immunohistochemical stainings were assessed in a series of randomly selected 5 high-power fields, considered to be representative of the average in tumors at x400 magnification, by two independent observers who were blinded to all clinical data. The sections were scored according to the proportion of positively stained tumor cells. For $\beta$-catenin staining, tumors with $>30 \%$ of cells showing definitive nuclear staining were regarded as positive cases.

Statistical analysis. All statistical analyses were performed using the statistical software SPSS 13.0 for Windows. The numerical data were statistically analyzed by the 2-tailed Student's t-test. Fisher's exact test was used to analyze the relationship between the levels of $\beta$-catenin expression and clinicopathological features. Bivariate correlation between two independent variables was calculated by the Spearman rank correlation coefficient. $\mathrm{P}<0.05$ was considered to indicate a statistically significant difference. 


\section{A}

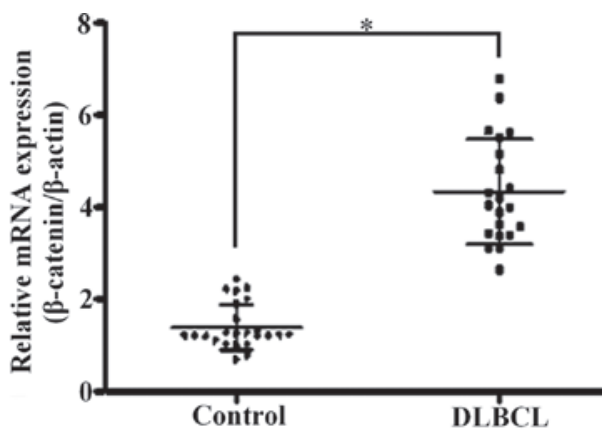

B

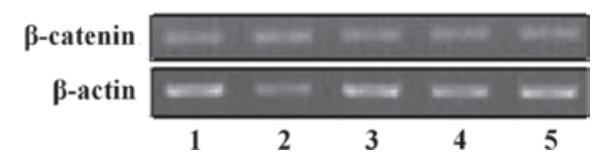

Figure 1. Real-time PCR analysis of $\beta$-catenin expression in DLBCL and reactive hyperplasia of lymph nodes (control). PCR products were confirmed as a single product at the desired size on aragose gels (lanes 1-3, DLBCL; lanes 4 and 5, control). $\beta$-actin served as a loading control. Data are expressed as the means $\pm \mathrm{SD}$. ${ }^{\mathrm{p}} \mathrm{p}<0.0001$ vs. control.

A

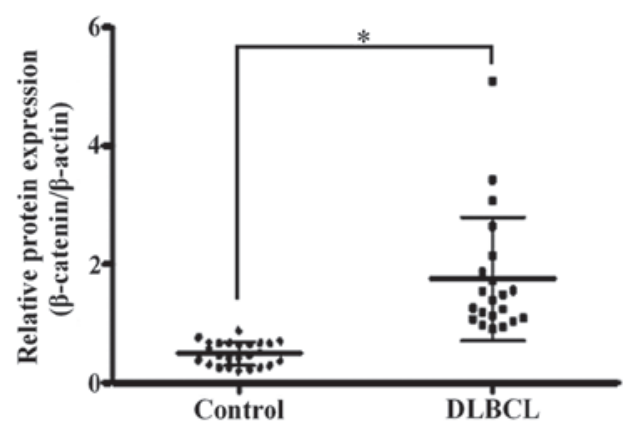

B

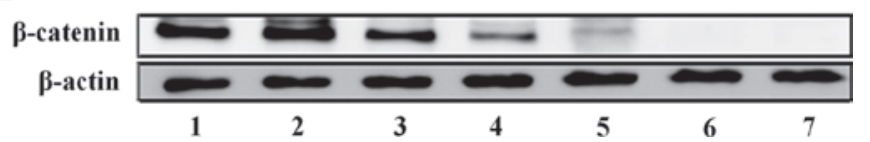

Figure 2. Expression of total $\beta$-catenin protein in DLBCL (lanes 1-4) and reactive hyperplasia of lymph node tissues (lanes 5-7). Expression levels were normalized with $\beta$-actin. Data are expressed as the means \pm SD. ${ }^{*} \mathrm{p}<0.0001$ vs. control.

\section{Results}

Overexpression of $\beta$-catenin in $D L B C L$. In the present study, the mRNA expression of $\beta$-catenin was determined using real-time quantitative PCR and western blotting in DLBCL and reactive hyperplasia of the lymph nodes. As illustrated in Figs. 1 and 2,DLBCL showed higher expression of $\beta$-catenin in contrast to that in the hyperplasia tissue at both the mRNA and protein levels $(\mathrm{P}<0.0001)$.

Expression of nuclear $\beta$-catenin in DLBCL tumors. $\beta$-catenin is a transcriptional factor that migrates to the nucleus and mediates the activation of the Wnt/ $\beta$-catenin pathway. To assess its nuclear localization and to further determine whether $\beta$-catenin protein overexpression is associated with clinicopathological characteristics of DLBCL, a cohort of paraffin-embedded, archived DLBCL tissues $(n=30)$ and reactive hyperplasia of lymph node tissues $(n=20)$ were examined
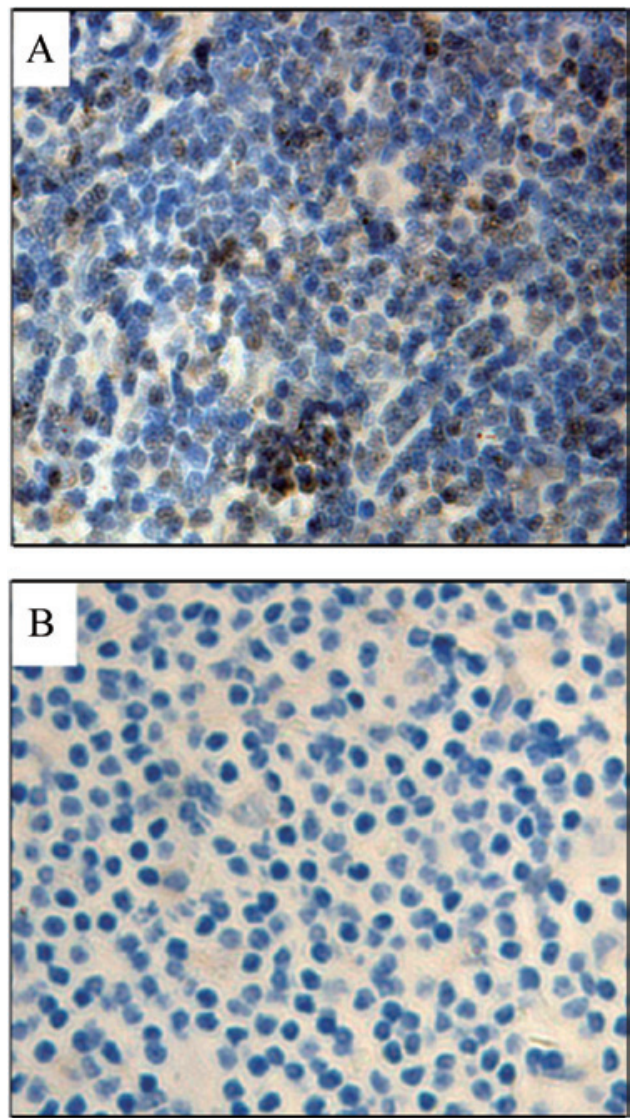

Figure 3. $\beta$-catenin expression as detected by immunohistochemical staining. (A) DLBCL. (B) Reactive hyperplasia of the lymph nodes. Original magnification, $\mathrm{x} 400$.

by immunohistochemical staining with an antibody against human $\beta$-catenin. The staining results are shown in Fig. 3A. Nuclear $\beta$-catenin was observed in $14(46.67 \%)$ DLBCL cases, whereas no nuclear accentuation of $\beta$-catenin was found in the inflammatory lymph node tissue (Fig. 3B). In the positive DLBCL cases, $\beta$-catenin staining was mainly nuclear, and a weak cytoplasmic staining was also detectable. There was only little or no cytoplasmic staining of $\beta$-catenin in reactive hyperplasia of lymph nodes. Consistent with the previous studies, these results demonstrate that the $\mathrm{Wnt} / \beta$-catenin pathway is partly activated in DLBCL and may be associated with the pathogenesis of DLBCL.

Relationship between $\beta$-catenin upregulation and the clinicopathological characteristics of DLBCL. Statistical analyses were performed to examine the correlation between the expression of the $\beta$-catenin protein and the clinical features of DLBCL. As shown in Table I, no correlation was found between $\beta$-catenin expression and patient age $(\mathrm{P}=1.000)$, gender $(\mathrm{P}=0.466)$ or $\mathrm{B}$ symptoms $(\mathrm{P}=0.713)$. Nevertheless, the expression levels of $\beta$-catenin protein were strongly correlated with the clinical staging of patients with DLBCL $(\mathrm{P}<0.001)$. To further confirm the correlation between $\beta$-catenin expression and clinicopathological characteristics, Spearman correlation analysis was performed. Spearman correlation of $\beta$-catenin expression levels to clinical staging was $0.788(\mathrm{P}=0.000)$. Taken together, these results indicate that the overexpression 
Table I. Correlation between $\beta$-catenin expression and the clinicopathological characteristics of DLBCL patients.

\begin{tabular}{lccc}
\hline Characteristics & \multicolumn{2}{c}{$\beta$-catenin expression } & \multirow{2}{*}{ P-value $^{\mathrm{a}}$} \\
\cline { 2 - 3 } & Negative (\%) & Positive (\%) & \\
\hline Age (years) & & & \multirow{2}{*}{1.000} \\
$<60$ & $11(68.80)$ & $9(64.30)$ & \\
$\geq 60$ & $5(31.20)$ & $5(35.70)$ & \\
Gender & & & 0.466 \\
Male & $9(56.30)$ & $10(71.40)$ & \\
Female & $7(43.70)$ & $4(28.60)$ & \\
Clinical stage & & & \\
I & $13(81.25)$ & $1(7.14)$ & \\
II & $2(12.50)$ & $3(21.43)$ & \\
III & $1(6.25)$ & $2(14.29)$ & \\
IV & $0(0.00)$ & $8(57.14)$ & \\
B symptoms & & & \\
Yes & $6(37.50)$ & $7(50.00)$ & \\
No & $10(62.50)$ & $7(50.00)$ & \\
\hline
\end{tabular}

${ }^{\mathrm{a} F i s h e r ' s ~ e x a c t ~ t e s t . ~}$

and nuclear localization of $\beta$-catenin are associated with the clinical progression of DLBCL.

\section{Discussion}

The Wnt/ $\beta$-catenin signaling pathway plays a significant role in embryonic development and in the maintenance of organs and tissues in adults $(10,11)$. The $\mathrm{Wnt} / \beta$-catenin pathway is also significantly involved in the progression of numerous types of carcinomas, including leukemia, myeloma (16-19) and several subtypes of lymphoma (20-29). It is known that activation of the Wnt/ $\beta$-catenin pathway could be important for malignancy of DLBCL. The GEP of one rituximab unresponsive and two responsive DLBCL cell lines showed that in the responsive cells rituximab affected the expression of genes in classical signaling cascades involved in cell growth and differentiation, such as previously identified MAPK and the completely novel Wnt and TGF- $\beta$ pathways (9).

$\beta$-catenin, the critical effector of the Wnt $/ \beta$-catenin signaling pathway, regulates a number of key processes during development, including proliferation, differentiation, survival, cell polarity and even angiogenesis. $\beta$-catenin is generally localized to the cell adhesion junctions in epithelial cells and, in certain cases, it is accumulated in the nucleus, mediates the activation of the Wnt/ $\beta$-catenin pathway and drives uncontrolled transcription of target genes (including c-jun, cyclin D1, c-myc and MMP-7) regulating cell proliferation, survival and cell adhesion (12). $\beta$-catenin has recently been shown to play a role in the survival and proliferation of normal murine $\mathrm{CD}^{+}$ $\mathrm{T}$ cells (32). In normal resting peripheral blood lymphocytes, $\beta$-catenin is continuously degraded (33), to the extent that it is undetectable by western blot analysis (33-35).

Numerous studies have demonstrated that deregulation of $\beta$-catenin is involved in the pathogenesis of a range of diseases, including several types of carcinomas (12). Nevertheless, the expression and localization of $\beta$-catenin have not yet been investigated in DLBCL. In the present study, we validated the upregulation of total $\beta$-catenin at both the mRNA and protein levels and the expression of nuclear $\beta$-catenin in DLBCL clinical specimens. This is in contrast to the situation in reactive hyperplasia of lymph node tissues, in which no nuclear accentuation of $\beta$-catenin was found.

In our study, 14 (46.67\%) DLBCL samples showed nuclear accentuation of $\beta$-catenin analyzed by immunohistochemical staining, while only little or no cytoplasmic staining of $\beta$-catenin was detected in reactive hyperplasia of lymph node tissues. Further statistical analyses of the relationship between $\beta$-catenin staining and the clinical features of DLBCL patients suggest that the nuclear accentuation of $\beta$-catenin is strongly correlated with the clinical staging of patients with DLBCL, whereas it is not correlated with patient age, gender or B symptoms.

In summary, the results clearly indicate that $\beta$-catenin was markedly overexpressed with nuclear localization in DLBCL tissues compared to their counterparts. We found that the nuclear accentuation of $\beta$-catenin was strongly correlated with the clinical staging of patients with DLBCL. Our findings suggest that the $\mathrm{Wnt} / \beta$-catenin pathway may contribute to the pathogenesis of DLBCL and could be a potentially useful therapeutic target for DLBCL.

\section{Acknowledgements}

This study was supported by grants from the Natural Science Foundation of Shandong Province, China (no. 2007C053 and no. ZR2009CM059), and the Project of Scientific and Technological Development of Shandong Province, China (no. 2007GG10002008).

\section{References}

1. The Non-Hodgkin's Lymphoma Classification Project: A clinical evaluation of the International Lymphoma Study Group classification of non-Hodgkin's lymphoma. Blood 89: 3909-3918, 1997.

2. Muris JJ, Cillessen SA, Vos W, et al: Immunohistochemical profiling of caspase signaling pathways predicts clinical response to chemotherapy in primary nodal diffuse large B-cell lymphomas. Blood 105: 2916-2923, 2005.

3. Swerdlow SH, Campo E, Harris NL, et al: WHO Classification of Tumours of Haematopoietic and Lymphoid Tissues. 4th edition. IARC Press, Lyon, pp233-237, 2008.

4. Abid MB, Nasim F, Anwar K and Pervez S: Diffuse large B cell lymphoma (DLBCL) in Pakistan: an emerging epidemic? Asian Pac J Cancer Prev 6: 531-534, 2005.

5. Smith PG, Wang F, Wilkinson KN, et al: The phosphodiesterase PDE4B limits cAMP-associated PI3K/AKT-dependent apoptosis in diffuse large B-cell lymphoma. Blood 105: 308-316, 2005.

6. Lam LT, Davis RE, Pierce J, et al: Small molecule inhibitors of IkappaB kinase are selectively toxic for subgroups of diffuse large B-cell lymphoma defined by gene expression profiling. Clin Cancer Res 11: 28-40, 2005.

7. Houldsworth J, Olshen AB, Cattoretti G, et al: Relationship between REL amplification, REL function, and clinical and biologic features in diffuse large B-cell lymphomas. Blood 103: 1862-1868, 2004

8. Uddin S, Hussain AR, Siraj AK, et al: Role of phosphatidylinositol 3'-kinase/AKT pathway in diffuse large B-cell lymphoma survival. Blood 108: 4178-4186, 2006.

9. Koivula S, Valo E, Raunio A, Hautaniemi S and Leppä S: Rituximab regulates signaling pathways and alters gene expression associated with cell death and survival in diffuse large B-cell lymphoma. Oncol Rep 25: 1183-1190, 2011. 
10. Moon RT: Wnt/beta-catenin pathway. Sci STKE 271: $\mathrm{cm} 1$, 2005.

11. Fodde $\mathrm{R}$ and Brabletz T: Wnt/beta-catenin signaling in cancer stemness and malignant behavior. Curr Opin Cell Biol 19: 150-158, 2007.

12. Clevers $\mathrm{H}$ : Wnt/beta-catenin signaling in development and disease. Cell 127: 469-480, 2006.

13. Rubinfeld B, Albert I, Porfiri E, Fiol C, Munemitsu S and Polakis P: Binding of GSK3beta to the APC-beta-catenin complex and regulation of complex assembly. Science 272: 1023-1026, 1996.

14. Peifer M: Beta-catenin as oncogene: the smoking gun. Science 275: 1752-1753, 1997.

15. Ge X and Wang X: Role of Wnt canonical pathway in hematological malignancies. J Hematol Oncol 3: 33, 2010

16. Herbst A and Kolligs FT: Wnt signaling as a therapeutic target for cancer. Methods Mol Biol 361: 63-91, 2007.

17. Reya T, Duncan AW, Ailles L, et al: A role for Wnt signalling in self-renewal of haematopoietic stem cells. Nature 423: 409-414, 2003.

18. Román-Gómez J, Cordeu L, Agirre X, et al: Epigenetic regulation of Wnt-signaling pathway in acute lymphoblastic leukemia. Blood 109: 3462-3469, 2007.

19. Bjorklund CC, Ma W, Wang ZQ, et al: Evidence of a role for activation of Wnt/beta-catenin signaling in the resistance of plasma cells to lenalidomide. J Biol Chem 286: 11009-11020, 2011.

20. Everly DN Jr, Kusano S and Raab-Traub N: Accumulation of cytoplasmic beta-catenin and nuclear glycogen synthase kinase 3beta in Epstein-Barr virus-infected cells. J Virol 78 $11648-11655,2004$.

21. Liu JJ, Dai XJ, Xu Y, et al: Inhibition of lymphoma cell proliferation by peroxisomal proliferator-activated receptor- $\gamma$ ligands via Wnt signaling pathway. Cell Biochem Biophys: Aug, 2011 (E-pub ahead of print).

22. Min HJ, Cho IR, Srisuttee R, et al: Hexachlorophene suppresses beta-catenin expression by up-regulation of Siah-1 in EBV-infected B lymphoma cells. Cancer Lett 276: 136-142, 2009.

23. Gelebart P, Anand M, Armanious H, Peters AC, Dien Bard J, Amin HM and Lai R: Constitutive activation of the Wnt canonical pathway in mantle cell lymphoma. Blood 112: 5171-5179, 2008.

24. Chung R, Peters AC, Armanious H, Anand M, Gelebart P and Lai R: Biological and clinical significance of GSK-3beta in mantle cell lymphoma - an immunohistochemical study. Int $\mathbf{J}$ Clin Exp Pathol 3: 244-253, 2010
25. Bellei B, Pacchiarotti A, Perez M and Faraggiana T: Frequent beta-catenin overexpression without exon 3 mutation in cutaneous lymphomas. Mod Pathol 17: 1275-1281, 2004.

26. Zhang D, O'Neil MF, Cunningham MT, Fan F, Olyaee M and $\mathrm{Li}$ L: Abnormal Wnt signaling and stem cell activation in reactive lymphoid tissue and low-grade marginal zone lymphoma. Leuk Lymphoma 51: 906-910, 2010.

27. Anand M, Lai R and Gelebart P: $\beta$-catenin is constitutively active and increases STAT3 expression/activation in anaplastic lymphoma kinase-positive anaplastic large cell lymphoma. Haematologica 96: 253-261, 2011.

28. Tandon B, Peterson L, Gao J, Nelson B, Ma S, Rosen S and Chen YH: Nuclear overexpression of lymphoid-enhancerbinding factor 1 identifies chronic lymphocytic leukemia/ small lymphocytic lymphoma in small B-cell lymphomas. Mod Pathol 24: 1433-1443, 2011.

29. Schmidt M, Sievers E, Endo T, Lu D, Carson D and Schmidt-Wolf IG: Targeting Wnt pathway in lymphoma and myeloma cells. Br J Haematol 144: 796-798, 2009.

30. Kawahara T, Kawaguchi-Ihara N, Okuhashi Y, Itoh M, Nara N and Tohda S: Cyclopamine and quercetin suppress the growth of leukemia and lymphoma cells. Anticancer Res 29: 4629-4632, 2009.

31. Jaffe ES, Harris NL, Stein H and Vardiman JW: Pathology and Genetics of Tumors of Hematopoetic and Lymphoid Tissues: World Health Organization Classification of Tumors. IARC Press, Lyon, p351, 2001.

32. Ding Y, Shen S, Lino AC, Curotto de Lafaille MA and Lafaille JJ: Beta-catenin stabilization extends regulatory $\mathrm{T}$ cell survival and induces anergy in nonregulatory T cells. Nat Med 14: 162-169, 2008.

33. Chung EJ LM, Lee S, Hwang S-G, Rubin JS and Trepel JB: Posttranslational Control of Beta-catenin Signaling Regulates Peripheral Blood Lymphocyte Activation. ASH Atlanta, Georgia, 2005.

34. Chung EJ, Hwang SG, Nguyen P, et al: Regulation of leukemic cell adhesion, proliferation, and survival by beta-catenin. Blood 100: 982-990, 2002.

35. Tomita M, Kikuchi A, Akiyama T, Tanaka Y and Mori N: Human T-cell leukemia virus type 1 tax dysregulates beta-catenin signaling. J Virol 80: 10497-10505, 2006. 